25.00.00 Geosciences

25.0о.оо Науки о Земле

UDC 378.147.88:303.442.23+50

\title{
Fieldpractice in Higher Education System. Resume of IV International Conference in the Crimea
}

\author{
1Vladimir V. Arkadiev \\ ${ }^{2}$ Galina P. Pekhar \\ ${ }^{3}$ Sergey M. Snigirevsky \\ ${ }^{4}$ Natalija V. Platonova \\ ${ }^{5}$ Olesya V. Bobrovskaya \\ ${ }^{6}$ Igor A. Garbuz \\ ${ }^{7}$ Elena P. Kayukova \\ ${ }^{8}$ Natalja P. Legenkova \\ ${ }^{9}$ Denis M. Mirin \\ ${ }^{10}$ Igor N. Polovtsev \\ ${ }^{11}$ Anastasija P. Chernyateva \\ 12 Viktor V. Yudin
}

1, 3-11 Saint-Petersburg State University, Russia

7/9 Universitskaya emb., Saint-Petersburg, 199034

${ }^{1}$ Dr.Sc (Geology), Professor, Scientific Chief of geological practice in Crimea

E-mail:arkad@gg2686.spb.edu

2 Bakhchisaray District State Administration, Crimea, Ukraine

5 Sovetskaya str., Bakhchisaray, Crimea, 98400

MSc (Education), First deputy Chairman of the Administration, Honored worker of education of Crimea

$3 \mathrm{PhD}$ (Geology), Head of Representative Office of Saint-Petersburg State University in the Autonomous Republic of Crimea, Senior Lecturer (Paleontology),

E-mail: s.snig@mail.ru

${ }^{4} \mathrm{PhD}$ (Geology), Associate Professor (Crystallography),

E-mail: platonova@crystal.pu.ru

${ }^{5}$ MSc (Geology), Engineer-Researcher (Geology)

E-mail: olesya-bobrovskaya@yandex.ru

${ }^{6} \mathrm{PhD}$ (History), Assistant Professor (Archeology),

E-mail: Igor.garbuz@gmail.com

${ }^{7}$ MSc (Geology), Senior Lecturer (Hydrogeology),

E-mail:epkayu@gmail.com

${ }^{8}$ MSc (Physics), Programmer (Physics of the Earth Department),

E-mail: legen@geo.phys.spbu.ru.

${ }_{9} \mathrm{PhD}$ (Biology), Associate Professor (Botany and ecology)

E-mail: mirin denis@mail.ru

${ }^{10}$ BSc (Physics), MSc (Management), CBA, Deputy Head of Building \& Reconstruction Division,

E-mail: i.polovtsev@spbu.ru

${ }_{11}$ MSc (Geology), Engineer-Researcher (Geology),

E-mail: nastya250@mail.ru

12 National Academy of Environmental Protection and Resort Development, Simferopol, Ukraine

181 Kievskaya str., Simferopol, Crimea, 95439, Ukraine

Dr.Sc (Geology), Professor, Full-member of Crimean Academy of Sciences,

E-mail: yudin_v_v@mail.ru

ABSTRACT. Brief information on the IV International Conference Field Practice in the Higher Education System held in the Crimea. Field practice is a part of educational program when 
students go to other regions in summer to apply on-site the competences and skills they obtained. Field practice is widely used in training of geologists, biologists, geophysicists, historians etc.

Keywords: conference; higher education; student practice; field practice; geosciences; geology; archaeology; Crimea.

The IV International Conference "Field practice in the Higher Education System" was held on the basis Representative office of Saint-Petersburg State University in the Autonomous Republic of the Crimea, Ukraine (the village of Trudoljubovka, Bakhchisaray region) from J uly 28 to August 7, 2012. The Conference was dedicated to the 80th anniversary of the Faculty of Geology of SaintPetersburg State University, the 60th anniversary of the Crimean geological field practice of Leningrad (now Saint-Petersburg) State University [1] and the memory of Professor Vladimir Anatolyevich Prozorovskiy.

The conference of teachers of higher educational institutions of the Soviet Union held at the Crimean geological training facility of Moscow State University in 1974 adopted a resolution to regard the geological field practice as an obligatory component of the academic process. Since then, all higher educational institutions training specialists in the field of geology arrange for summer field practice for the students of the first, second and third year of studies.

In 2002, Saint-Petersburg State University revived the tradition of holding conferences dedicated to field practice [2]. The second conference Field practice in the Higher Education System was held in the Crimea in 2007 [3, 4]. The third conference held in Gorny Altai in 2009 was organised by Novosibirsk State University, Novosibirsk State Pedagogical University and the Institute of Archaeology and Ethnography, Siberian Branch of the Russian Academy of Sciences [5, 6].

Now these conferences discuss not only the issues of practice for the students of geological specialities. Field practice was included into the training programs for geographers, archaeologists, biologists and geophysicists.

The present conference was attended by more than 160 participants from 54 higher educational establishments and research and development organisations of Russia, the Ukraine, Belarus, Moldova, Poland, Abkhazia and China with 100 reports. The conference represented not only capital cities such as Moscow, Kiev, Minsk, Kishinev, Saint-Petersburg and Sukhum, but also Arkhangelsk, Alchevsk (Ukraine), Balashov (Russia), Vladimir, Grozny, Dnepropetrovsk, Izhevsk, Kazan, Kaliningrad, Kemerovo, Kremenets (Ukraine), Lviv, Mogilev, Novosibirsk, Nizhny Novgorod, Omsk, Orenburg, Petrozavodsk, Rostov-on-don, Ryazan, Samara, Saratov, Sevastopol, Simferopol, Sumy (Ukraine), Syktyvkar, Tomsk, Tyumen, Fuzhou (China), Khanty-Mansiysk, Yakutsk.

Members of conference discussed the history of field practice for students, its role and place in the academic process; methodological issues of organisation of field practice; prospects of development of field practice; the issues of geology, biology, environmental protection and archaeology of the Crimea.

Field practice is the major element of the present-day training of specialists (both bachelors and masters) in geology, hydrogeology, environmental protection, archaeology, geobotany, soil science, geography, zoology, philology, cultural science etc. The conference expressed its concern with drastic reduction of financing of field practice. The reduction cannot but lower the quality of training of the university graduates.

The conference recommended to the Ministries of Education of Russia, the Ukraine, Belarus and Moldova to retain field practice in the bachelor and master training programs. It was recognised indispensable to step up financing and improve technical provision of field practice facilities.

The conference also pointed out the necessity for different universities to coordinate the methodological bases of field practices in each speciality.

The conference recommended expanding international contacts of field practice facilities of different universities and making contracts with foreign universities for field practice exchange of teachers and students.

The conference charged Professor of Saint-Petersburg State University, Vladimir Arkadyev, to be the science editor of the inter-university book of articles on geology of the Crimea.

The V International Conference was suggested to be held in 2014 in the Pinega State Reserve of Arkhangelsk province, Russia. Traditionally, the VI Conference will be held in 2017 in 
Representative Office of Saint-Petersburg State University in the Autonomous Republic of Crimea, Ukraine.

During the conference was organized tours through Trudoljubovka region (Bakhchisaray and surrounding areas) - geology, geomorphology, ecology, soils and vegetation, Archaeology of the Crimea. Various Mesozoic and Cenozoic marine deposits and volcanic-sedimentary formations are located in the river Bodrak basin. The deposits represent a great diversity of marine fauna remains (ammonites, belemnites, bivalves and gastropods, corals, brachiopods, echinoderms, sponges, bryozoans). Due to the excellent rock outcrops we will be able to see different tectonic structures like monoclinal, folded, ruptured, etc. The unique cuesta topography is very typical for the Crimean Mountains. In South-West Crimea the modern geological processes including earthquakes, landslides, erosion, etc are widely exhibited. Numerous archaeological objects like ancient burials, cave "cities" (Bakla cave fort near of the river Bodrak, cave monasteries of Chufut-Calais, MangupCalais, etc.) are of additional interest. All of this determines the favorable conditions for practice performing and for studying the various topics of geology, archeology and history.

After the breakout and plenary sessions had been over, the participants of the conference enjoyed two four-day tours of the Crimea [7]. The tour of the Eastern Crimea was conducted by Professor Vladimir Arkadyev and Senior Lecturer Elena Kayukova (Trudoljubovka - mount AkKaya - Kazantip Bay of the Azov sea - Bulganak field of mud volcanoes - Kerch - Cape Opuk - Kojas mud-a salt lake, excavations of the ancient city Kimmerik - Feodosiya - Trudoljubovka). The tour of the Western Crimea was operated by Dr. (Geology) Sergey Snigirevsky and Dr. (History) Igor Garbuz (Trudoljubovka - greek-scythian site of ancient settlement of Kara-Tobe - Evpatoria excavations at the site tourist - settlement Kulchuk - Beljaus - Tarkhankut peninsula - Dzhangul landslide processes - the ancient greek city Kalos-Limen - salt lake Bakol - Bakal spit Trudoljubovka).

The conference materials were published by St Petersburg State University as a abstractsvolume [8]. The conference materials are to be placed in the web portal of Field Practice [9] established by decision of the III International Conference.

\section{REFERENCES:}

1. Prozorovskiy V.A. 50 years in the Crimea. / Geology of the Crimea. Proceedings of the Department of Historical Geology. Issue 2. Saint-Petersburg: Earth Crust Institute of Saint-Petersburg State University, 2002. p. 8-23; Available at: URL: http://rogov.zwz.ru/crimea/03/2002.Geologija.Kryma.pdf (access of 31.08.2012).

2. Field practice in the natural-science education system of universities of Russia and abroad: international conference proceedings (August 5-15, 2002). Saint-Petersburg, 2002. 83 p.

3. Field practice in the higher education system. II International Conference: abstracts. SaintPetersburg: VVN, 2007. 324 p. ISBN 5-9651-0179-1.

4. Arkadyev V.V., Kashkevich M.P., Kayukova Y.P., Mirin D.M., Snigirevskiy S.M. II International Crimean Conference Field Practice in the Higher Education System // Vestnik of Saint-Petersburg University. Series 7: Geology. Geography. 2008. №3. p.147-154; Available at: URL: http:// elibrary.ru/item.asp?id=12883049 (access of 31.08.2012).

5. Field practice in the higher education system: III International Conference proceedings (Altai, August 21-29, 2009). Novosibirsk: Novosibirsk State University, 2009. 231 p. ISBN 978-5-94356-806-0.

6. Borodovskiy A.P., Novikova O.I. III International Conference Field Practice in the Higher Education System // Vestnik of Novosibirsk State University. Series: History. Philology. 2009. T. 8, № 5 . p.326-327; Available at: URL: http:/ / elibrary.ru/ item.asp?id=12990311 (access of 31.08.2012).

7. Arkadyev V.V. Geological tours of the Crimea. Saint-Petersburg: Publishing house RGPU by A.I.Gertzen, 2010. 132 p. ISBN 978-5-8064-1503-6; Available at: URL: http:// cretaceous.ru/ pub/ /id/ 1396 (access of 31.08.2012).

8. Field practice in the higher education system. IV International Conference: abstracts. Simferopol: DIAJ PI, 2012. 304 p. ISBN 978-966-491-313-0; Available at: URL: http://cretaceous.ru/pub/ /id/ 1635 (access of 31.08.2012).

9. Field practice. [web site] URL: http:// polprakt.nsu.ru (access of 31.08.2012). 
УДК 378.147.88:303.442.23+50

\title{
Полевые практики в системе высшего профессионального образования. Итоги IV-й международной конференции в Крыму
}

\author{
${ }^{1}$ Владимир Владимирович Аркадьев \\ 2 Галина Петровна Пехарь \\ ${ }^{3}$ Сергей Михайлович Снигиревский \\ ${ }^{4}$ Наталия Владимировна Платонова \\ ${ }^{5}$ Олеся Васильевна Бобровская \\ ${ }^{6}$ Игорь Анатольевич Гарбуз \\ ${ }^{7}$ Елена Павловна Каюкова \\ ${ }^{8}$ Наталья Петровна Легенькова \\ 9 Денис Моисеевич Мирин \\ ${ }^{10}$ Игорь Николаевич Половцев \\ ${ }^{11}$ Анастасия Петровна Чернятьева \\ ${ }^{12}$ Виктор Владимирович Юдин
}

1, 3-11 Санкт-Петербургский государственный университет, Россия

Университетская наб.7/9, Санкт-Петербург, 199034

1 Доктор геолого-минералогических наук, профессор

E-mail:arkad@gg2686.spb.edu

2 Бахчисарайская районная государственная администрация АР Крым, Украина

ул. Советская 5, Бахчисарай, Автономная Республика Крым, 98400

Первый заместитель председателя райгосадминистрации

3 Кандидат геолого-минералогических наук, директор Представительства СанктПетербургского государственного университета в Автономной Республике Крым Украины

E-mail: s.snig@mail.ru

${ }^{4}$ Кандидат геолого-минералогических наук, доцент

E-mail: platonova@crystal.pu.ru

${ }^{5}$ Инженер-исследователь

E-mail: olesya-bobrovskaya@yandex.ru

${ }^{6}$ Кандидат исторических наук, ассистент кафедры

E-mail: Igor.garbuz@gmail.com

${ }^{7}$ Старший преподаватель

E-mail:epkayu@gmail.com

${ }^{8}$ Программист лаборатории

E-mail: legen@geo.phys.spbu.ru.

${ }^{9}$ Кандидат биологических наук, доцент

E-mail: mirin denis@mail.ru

10 Заместитель начальника управления капитального строительства и реконструкции,

E-mail: i.polovtsev@spbu.ru

${ }^{11}$ Инженер-исследователь геологического факультета

E-mail: nastya250@mail.ru

12 Национальная академия природоохранного и курортного строительства, Украина

ул. Киевская 181, Симферополь, АР Крым, 95439

Доктор геолого-минералогических наук, профессор

E-mail: yudin_v_v@mail.ru

Аннотация. Краткая информация о проведенной в Крыму IV-й международной конференции «Полевые практики в системе высшего профессионального образования». Полевые практики - это выезд студентов летом в другие регионы для применения на местности полученных знаний и навыков. Практики широко используются при обучении геологов, биологов, геофизиков, историков и других специалистов.

Ключевые слова: конференция; высшее образование; студенческие практики; полевые практики; науки о земле; геология; археология; Крым. 